\title{
Decolorization of Anthraquinonic Dyes from Textile Effluent Using Horseradish Peroxidase: Optimization and Kinetic Study
}

\author{
Nataša Ž. Šekuljica, ${ }^{1}$ Nevena Ž. Prlainović, ${ }^{2}$ Andrea B. Stefanović, ${ }^{1}$ Milena G. Žuža, \\ Dragana Z. Čičkarić, ${ }^{1}$ Dušan Ž. Mijin, ${ }^{1}$ and Zorica D. Knežević-Jugović ${ }^{1}$ \\ ${ }^{1}$ Faculty of Technology and Metallurgy, University of Belgrade, Karnegijeva 4, 11000 Belgrade, Serbia \\ ${ }^{2}$ Innovation Center, Faculty of Technology and Metallurgy, University of Belgrade, Karnegijeva 4, 11000 Belgrade, Serbia \\ Correspondence should be addressed to Zorica D. Knežević-Jugović; zknez@tmf.bg.ac.rs
}

Received 15 September 2014; Accepted 25 December 2014

Academic Editor: Khalid Z. Elwakeel

Copyright (C) 2015 Nataša Ž. Šekuljica et al. This is an open access article distributed under the Creative Commons Attribution License, which permits unrestricted use, distribution, and reproduction in any medium, provided the original work is properly cited.

\begin{abstract}
Two anthraquinonic dyes, C.I. Acid Blue 225 and C.I. Acid Violet 109, were used as models to explore the feasibility of using the horseradish peroxidase enzyme (HRP) in the practical decolorization of anthraquinonic dyes in wastewater. The influence of process parameters such as enzyme concentration, hydrogen peroxide concentration, temperature, dye concentration, and $\mathrm{pH}$ was examined. The $\mathrm{pH}$ and temperature activity profiles were similar for decolorization of both dyes. Under the optimal conditions, 94.7\% of C.I. Acid Violet 109 from aqueous solution was decolorized (treatment time $15 \mathrm{~min}$, enzyme concentration $0.15 \mathrm{IU} / \mathrm{mL}$, hydrogen peroxide concentration $0.4 \mathrm{mM}$, dye concentration $30 \mathrm{mg} / \mathrm{L}, \mathrm{pH} 4$, and temperature $24^{\circ} \mathrm{C}$ ) and $89.36 \%$ of C.I. Acid Blue 225 (32 min, enzyme concentration $0.15 \mathrm{IU} / \mathrm{mL}$, hydrogen peroxide concentration $0.04 \mathrm{mM}$, dye concentration $30 \mathrm{mg} / \mathrm{L}$, $\mathrm{pH}$, and temperature $24^{\circ} \mathrm{C}$ ). The mechanism of both reactions has been proven to follow the two substrate ping-pong mechanism with substrate inhibition, revealing the formation of a nonproductive or dead-end complex between dye and $\mathrm{HRP}$ or between $\mathrm{H}_{2} \mathrm{O}_{2}$ and the oxidized form of the enzyme. Both chemical oxygen demand and total organic carbon values showed that there was a reduction in toxicity after the enzymatic treatment. This study verifies the viability of use of horseradish peroxidase for the wastewaters treatment of similar anthraquinonic dyes.
\end{abstract}

\section{Introduction}

Synthetic dyes are a major class of pollutants in wastewater from various industries such as textile, paper, food, plastics, and cosmetics. Today, over 100,000 different dye structures have been synthesized and more than 0.7 million tons of dyestuff are produced annually [1]. Dyes represent a very large and complex group of organic compounds, which differ in their origin, chemical and/or physical properties, and characteristics related to the application process. They are broadly classified according to their application (the dyeing method) into groups as acid or basic dyes, disperse dyes, direct dyes, mordant dyes, reactive dyes, vat dyes, and so forth, or on the bases of their chemical structure as azo dyes, anthraquinonic dyes, carotenoid dyes, xanthene dyes, triphenylmethane dyes, phthalocyanine, and so forth. Up to
$50 \%$ of the dyes used in textile dyeing may remain unfixed to the fiber and contaminates the industrial wastewater [2].

In wastewaters, dyes are easily noticeable since they can be observed at lower concentrations starting from $1 \mathrm{mg} / \mathrm{L}$ [2]. In addition, the effects caused by other pollutants in textile wastewater and the presence of very small amounts of dyes in the water, which are nevertheless highly visible, seriously affect the aesthetic quality and transparency of lakes, rivers and others, leading to damage to the aquatic environment and formation of dead deoxygenated zones in seas and oceans $[3,4]$. The more complex environmental problems associated with the textile wastewaters, besides the coating, are due to wide utilization of carcinogenic or mutagenic dyes, which are resistant to acid and basic conditions, bleaching agents, light degradation, and others $[5,6]$. 
Anthraquinonic dyes are a major class of these environmental colored pollutants due to their recalcitrance and high toxicity and their environmental release by diverse industries [7]. Many of anthraquinonic dyes are mutagenic and even carcinogenic and pose a serious threat to living organisms $[8,9]$. For example, amongst two azo- (Reactive Orange 16; Congo Red) and two anthraquinonic dyes (Remazol Brilliant Blue R (RBBR); Disperse Blue 3 (DB3)) tested, the anthraquinone DB3 dye has been proven to be the most toxic in the bacterial, algal, and protozoan tests, exhibiting mutagenic effects after metabolic activation in vitro in all $S$. typhimurium strains used [10]. Also, they are very resistant to degradation due to their fused aromatic structures and remain colored for a long time, which makes them obligatory to remove from industrial effluents before being discharged into the environment. Therefore, two acid anthraquinonic dyes, C.I. Acid Blue 225 and C.I. Acid Violet 109, widely used for wool, polyamide, silk, and the blended fibers dyeing and printing, were selected as models for current study.

Various strategies have been used to remove dyes from textile wastewater and reduce the cost of the overall process including chemical oxidation, physicochemical techniques (coagulation/flocculation, adsorption, and reverse osmosis), electrochemical or microbial decolorization, and, most recently, the use of various enzymes. The use of physical/chemical methods has numerous drawbacks such as: economical unwarrancy (spending a huge amount of chemicals and energy), incomplete dye removal, generating a large amount of mud that can cause a secondary pollution problem, and price augmentation of these methods which is a result of implementation of complicated processes [11]. In contrast to physical/chemical methods, certain biological methods have been developed and have shown themselves as economically more available, considerably more efficient, and ecofriendly for the removal of numerous toxic pollutants [12-14]. Especially, there is growing interest to the enzyme degradation of dyes due to several advantages such as greater specificity, capability to operate over a broad concentration range of contaminants, better standardization, easy handling and storage, and no dependence on bacterial growth rates $[15,16]$. Enzymes can act on specific recalcitrant pollutants to remove them by precipitation or transformation to other products. Amongst oxidoreductive enzymes that are involved in dye decolorization, peroxidases such as horseradish peroxidase (HRP), citochrome $\mathrm{C}$ peroxidase isolated from yeast, chloroperoxidase isolated from Caldariomyces fumago, several fungal lignin peroxidase (LiP) and manganese peroxidase (MnP) such as LiP from Phanerochaete chrysosporium, and soybean peroxidase have been reported as excellent oxidant agents to degrade dyes in the presence of hydrogen peroxide [17-21].

Peroxidases (EC 1.11.1.x) are chem consisting proteins (metaloproteins) which use hydrogen peroxide or other organic peroxides as electron acceptors to catalyze the oxidation of a wide range of substrates. Especially, HRP has shown potential for use as a bioremediation catalyst because of its ability to oxidize a large number of dyes even in the presence of contaminants commonly found in wastewaters, flexibility to function at wide ranges of temperature, $\mathrm{pH}$ and salinity, ready availability, and relatively low cost [20, 22-24]. Although HRP is highly specific to its peroxide substrate, of which $\mathrm{H}_{2} \mathrm{O}_{2}$ is the most common, it shows broad substrate specificity toward its hydrogen donor substrate, degrading also other aromatic compounds, such as phenol, estrogens, p-chlorophenol, and others [25]. Previously, several studies showed that HRP efficiently cleaved aromatic azo compounds in the presence of $\mathrm{H}_{2} \mathrm{O}_{2}$ and degraded and precipitated industrially important azo dyes [23, 26, 27]. However, the studies concerning HRP-catalyzed degradation of anthraquinonic dyes are rather scarce [7].

Dye structure has been shown to have significant effect on the decolorization ability of HRP. Although anthraquinonic dyes account for about $15 \%$ colorants, there are only few papers dealing with their degradation by HRP-catalyzed reaction. A better understanding of the mechanism and kinetics of this process would help in the design of a suitable reactor system through process development, optimization, and scale-up.

The aim of this study is to examine the feasibility of using the HRP to remove two selected anthraquinonic dyes from wastewaters. The influence of parameters such as enzyme concentration, dye concentration, hydrogen peroxide concentration, $\mathrm{pH}$ of aqueous solution, and temperature was examined in order to determine the optimal conditions for decolorization of anthraquinonic dyes. The present work also focuses on kinetic investigations based on the degradation of the anthraquinonic model dyes by this versatile enzyme.

\section{Materials and Methods}

2.1. Materials. Anthraquinonic dyes used in this paper, C.I. Acid Blue 225 (AB 225) and C.I. Acid Violett 109 (AV 109), are obtained from Lanaset (Lanaset Violet B, Lanaset Blue 2R) and their characteristics are presented in Table 1. HRP peroxidase (EC 1.11.1.7; donor: hydrogen peroxide oxidoreductase) with a specific activity of 250 purpurogallin units per mg was purchased from Sigma-Aldrich (St. Louis, MO, USA). All aqueous solutions were prepared in doubly distilled water. The concentration of hydrogen peroxide solutions was determined several times using its molar absorption coefficient $\left(\varepsilon=43.6 \mathrm{M}^{-1} \mathrm{~cm}^{-1}\right)$ at $\lambda=240 \mathrm{~nm}$ by dilution of the supplied $\mathrm{H}_{2} \mathrm{O}_{2}(30 \% \mathrm{v} / \mathrm{v})$ solution. Other chemicals used in this work were of commercial analytical grade.

2.2. Decolorization Experiments. In order to optimize process parameters for dye decolorization from textile wastewater with HRP, the influence of enzyme concentration, dye concentration, hydrogen peroxide concentration, $\mathrm{pH}$, and temperature was examined for both dyes. The dye (AV 109 or AB 225) was prepared in distilled water or appropriate buffer at concentration of $10-50 \mathrm{mg} / \mathrm{L}$ and a selected quantity of hydrogen peroxide was added. The solution was allowed to achieve thermal equilibrium, prior to reaction initiation and was stirred at $100 \mathrm{rpm}$ using magnetic stirring bars. Reactions were initiated by the addition of HRP in order to minimize any potential inactivation of the enzyme due to extreme $\mathrm{pH}$ values and peroxide and aliquots of $3 \mathrm{~mL}$ volume, were 
TAble 1: Analyzed anthraquinonic dyes properties.

Name: C.I. Acid Violet 109

Molecular structure: anthraquinones

Molecular formula: $\mathrm{C}_{35} \mathrm{H}_{34} \mathrm{Br}_{2} \mathrm{NaO}_{7} \mathrm{~S}$

Molecular weight: $823.52 \mathrm{~g} / \mathrm{mol}$

CAS registry number: $12220-63-2$

$\lambda_{\text {max }}: 590 ; 552 \mathrm{~nm}$<smiles>CC(=O)Nc1c(C)cc(C)c(Nc2cc(Oc3ccc(C)c(S(N)(=O)=O)c3)cc3c2C(=O)c2ccccc2C3=O)c1C</smiles><smiles>Cc1cc(C)c(Nc2cc(S(N)(=O)=O)c(N)c3c2C(=O)c2ccccc2C3=O)c(C)c1NC(=O)/C=C/Br</smiles>

Name: C.I. Acid Blue 225

Molecular structure: anthraquinones

Molecular formula: $\mathrm{C}_{26} \mathrm{H}_{20} \mathrm{Br}_{2} \mathrm{~N}_{3} \mathrm{O}_{6} \mathrm{~S}$

Molecular weight: $685.32 \mathrm{~g} / \mathrm{mol}$

CAS registry number: $12216-97-6$

$\lambda_{\text {max }}: 628 ; 589 \mathrm{~nm}$

a 
of $200-800 \mathrm{~nm}$ and optimum wavelength was determined $\left(\lambda_{\max }-628 \mathrm{~nm}\right.$, absorbance- 0.265 for $\mathrm{AB} 225$, and $\lambda_{\max }-$ $590 \mathrm{~nm}$, absorbance-0.319 for AV 109). The calculated molar extinction coefficients were $11,019 \mathrm{~L} \mathrm{mmol}^{-1} \mathrm{~cm}^{-1}$ and $6,053 \mathrm{~L} \mathrm{mmol}^{-1} \mathrm{~cm}^{-1}$ for AV 109 and AB 225, respectively.

The decolorization in percentage for both dyes was determined, according to the equation [28]

$$
\text { Decolorization }(\%)=\left[\frac{\left(A_{0}-A_{t}\right)}{A_{0}}\right] \times 100 \text {, }
$$

where $A_{0}$ is the initial absorbance of untreated dye solutions (control) and $A_{t}$ is the absorbance of dye solutions after enzymatic treatment.

Experiments were made in triplicates, and standard deviations were calculated.

2.5. Determination of the Chemical Oxygen Demand (COD) and Total Organic Carbon (TOC). In order to estimate the amount of organic matter in wastewater, the COD was examined. The test measures the amount of oxygen required for chemical oxidation of organic matter in the sample to carbon dioxide and water. COD was examined using the closed reflux method. The samples for COD experiment were prepared under previously determined conditions (for AV 109 dye: $\mathrm{pH} 4.0$, temperature $24^{\circ} \mathrm{C}$, hydrogen peroxide concentration $0.4 \mathrm{mM}$, dye concentration $30 \mathrm{mg} / \mathrm{L}$, and enzyme concentration $0.15 \mathrm{IU} / \mathrm{mL}$; for $\mathrm{AB} 225$ dye: $\mathrm{pH} 5.0$, temperature $24^{\circ} \mathrm{C}$, hydrogen peroxide concentration $0.04 \mathrm{mM}$, dye concentration $30 \mathrm{mg} / \mathrm{L}$, and enzyme concentration $0.15 \mathrm{IU} / \mathrm{mL}$ ). Briefly, $2 \mathrm{~mL}$ of the sample is pippeted into vials $(10 \mathrm{~mL}$ capacity and $19 \mathrm{~mm}$ diam.) containing $0.9 \mathrm{~mL}$ digestion solution (10.216 $\mathrm{g} \mathrm{K}_{2} \mathrm{CrO}_{7}, 167 \mathrm{~mL}$ conc. $\mathrm{H}_{2} \mathrm{SO}_{4}$, and $33.3 \mathrm{~g} \mathrm{HgSO}_{4}$ in $1 \mathrm{~L}$ distilled water) and $2.1 \mathrm{~mL}$ sulfuric acid reagent (1 kg conc. $\mathrm{H}_{2} \mathrm{SO}_{4}$ and $5.5 \mathrm{~g} \mathrm{Ag}_{2} \mathrm{SO}_{4}$ ). Water was used as the blank. The mixture is refluxed by COD reactor $\left(2 \mathrm{~h}, 148-150^{\circ} \mathrm{C}\right)$ and then cooled ( $45 \mathrm{~min}$ ). The COD determination is made with the spectrophotometer (HANNA, HI 83099).

Content of the total organic carbon was measured using standard SRPS ISO method 8245:2007 with the TOC-VCPA analyzer (Shimadzu Corporation).

\section{Results and Discussion}

3.1. Effect of Time on the Dye Decolorization. In this study the ability of HRP to decolorize two synthetic anthraquinonic dyes was investigated. The time course of dyes' decolorization by HRP is shown in Figure 1.

The time course of decolorization was apparently different for two dyes. Specifically, following 15 and 32 minutes of incubation, the decolorization percentage of AV 109 and AB 225 was $85.16 \%$ and $50.63 \%$, respectively. After mentioned time, there was no significant augmentation in the dye decolorization percentage with increasing contact time. The enzymatic process appeared to lead to a rather high decolorization percentage in the case of AV 109 for a short reaction time, revealing a rather high HRP decolorization efficiency toward this anthraquinonic dye. In the case of other oxidases such as laccase, the decolorization process

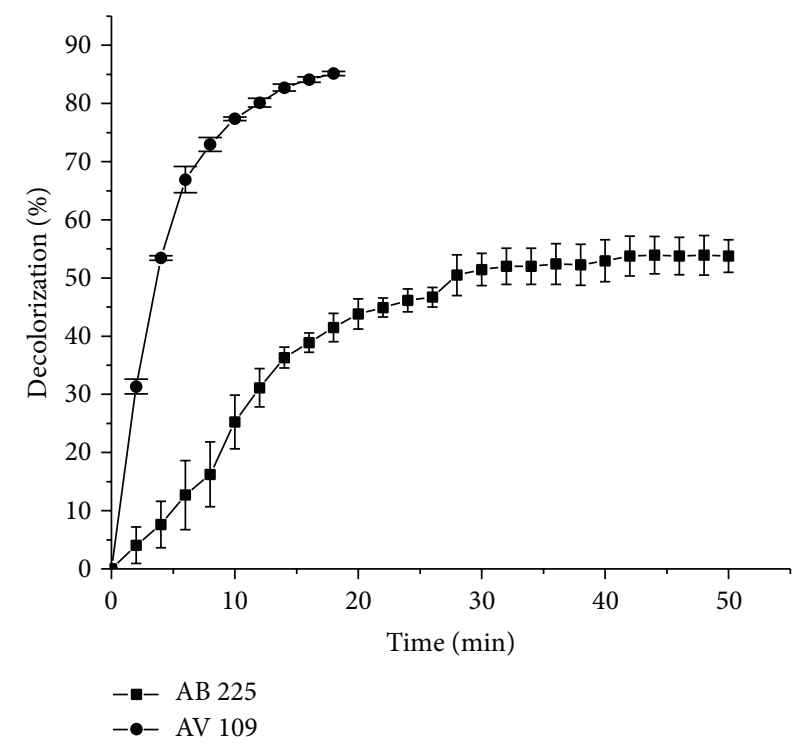

Figure 1: Time course of decolorization of AV 109 (circle) and $\mathrm{AB} 225$ (square) dyes at concentration of $30 \mathrm{mg} / \mathrm{L}$. Other reaction conditions for AV 109 dye: peroxide concentration $2 \mathrm{mM}, \mathrm{pH}$ 5.25, enzyme concentration $0.15 \mathrm{IU} / \mathrm{mL}$, temperature $24^{\circ} \mathrm{C}$; for $\mathrm{AB}$ 225 dye: hydrogen peroxide concentration $1 \mathrm{mM}, \mathrm{pH} 5.5$, enzyme concentration $0.04 \mathrm{IU} / \mathrm{mL}$, and temperature $24^{\circ} \mathrm{C}$.

of an anthraquinonic dye as a model was not observed in the absence of a small molecular weight redox mediator [29].

On the other hand, decolorization of this important class of recalcitrant anthraquinone-type dyes used in the textile industry has been verified by using laccase extracted from Polyporus sp. S133, but the reported system required longer reaction times. Specifically, the decolorization percentage was 26 and $60 \%$ after 24 and $48 \mathrm{~h}$ of incubation, respectively, and with $N$-hydroxybenzotriazole as a redox mediator it increased by $20 \%$ [30]. By comparison, other dyes such as diazo dye Acid Black 10 BX have been completely decolorized at dye concentration of $20 \mathrm{mg} / \mathrm{L}$ with $2.205 \mathrm{IU} / \mathrm{mL}$ of HRP activity and a $1 \mathrm{~h}$ treatment at dye concentration of $20 \mathrm{mg} / \mathrm{L}$ after 45 minutes [23].

It appeared that the affinity of HRP for AV 109 is higher than that for $A B 225$, suggesting that the dye structure has an important effect on the HRP activity through steric effects, electronic distribution or charge distribution. In addition, the ionisation potential could play an important role [31]. In this work, we selected two anthraquinonic dyes with similar chemical structures. AB 225 is a typical anthraquinonic dye used in the textile industry with a common paradiaminoanthraquinone sulfonated moiety substituted on the para-amino group. In addition, AB 225 have double bond on amide group. However, AV 109 lacks one amino group while other amino group is substituted with similar moiety. In para position to the substituted amino group, AV 109 have sulphonated phenoxy moiety. To our knowledge, there are no examples of the use of HRP as the catalyst for decolorization of these anthraquinonic dyes. Change in absorption spectrum 


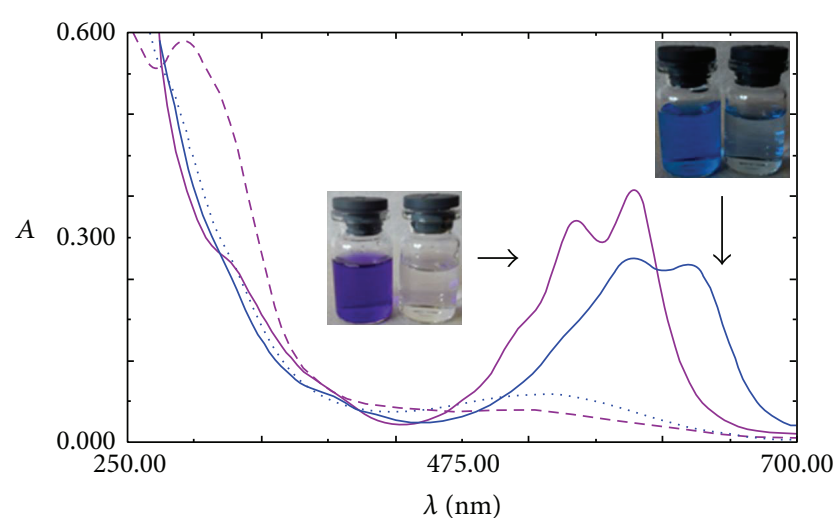

Figure 2: Absorption spectra before (solid lines) and after enzymatic decolorization experiment (dotted lines) for AB 225 (blue) and AV 109 (violet).

of the medium as a result of the enzymatic reaction has been presented in Figure 2 for both dyes.

3.2. Effect of the Initial Enzyme Concentration. Effect of the initial enzyme concentration on the dye decolorization was investigated in the range from 0.02 to $0.2 \mathrm{IU} / \mathrm{mL}$ for both dyes and results are presented in Figure 3.

It was apparent that the removal of both dyes increased with an increase in the initial enzyme concentrations. When the concentration reached $0.15 \mathrm{IU} / \mathrm{mL}, 83.68$ and $70.37 \%$ of $\mathrm{AV} 109$ and $\mathrm{AB} 225$ were removed, respectively. For the removal of the azo dye, Acid Black $10 \mathrm{BX}$, the enzyme concentration of $2.205 \mathrm{IU} / \mathrm{mL}$ was required which is fifteen times higher than in the case of the anthraquinonic dyes examined in this work [23]. On the other hand, Celebi et al. found out that the necessary enzyme concentration for removal of the anthraquinonic dye, Reactive Blue 19, was $3.30 \mu \mathrm{g} / \mathrm{mL}$ which is almost six times higher than the amount required for $\mathrm{AB} 225$ or $\mathrm{AV} 109$ dyes [7]. In the current research, the HRP concentration of $0.15 \mathrm{IU} / \mathrm{mL}$ was sufficient to achieve $83.7 \%$ or higher removal of AV 109 and AB 225, within only 32 and 15 minutes of treatment, respectively, suggesting its rather high potential for decolorization of these anthraquinonic dyes.

3.3. Initial Hydrogen Peroxide and Dye Concentration Influence. To examine the influence of hydrogen peroxide, its concentration was varied in the range from 0.1 to 1.0 and from 0.02 to $0.2 \mathrm{mM}$ for AV 109 and $\mathrm{AB} 225$, respectively. The ranges were selected in the preliminary study which revealed that the oxidation of AV 109 consistently required less hydrogen peroxide in comparison with AB 225. Results are shown in Figure 4(a).

The inhibitory effect of hydrogen peroxide was evident, particularly in the case of AB 225 (Figure 4(a)). Namely, an increase of the dye decolorization percentage was apparent in the hydrogen peroxide concentration range of $0.02-$ $0.04 \mathrm{mM}$. Further addition of hydrogen peroxide resulted in a decrease of dye removal. Although the requirement of $\mathrm{H}_{2} \mathrm{O}_{2}$ was significantly different from that for $\mathrm{AB} 225$,
TABLE 3: Optimal parameters for examined anthraquinonic dyes decolorization by HRP.

\begin{tabular}{lcc}
\hline Optimal & AV 109 & AB 225 \\
\hline $\mathrm{pH}$ & 4.0 & 5.0 \\
Temperature, ${ }^{\circ} \mathrm{C}$ & 24 & 24 \\
Hydrogen peroxide concentration, $\mathrm{mM}$ & 0.4 & 0.04 \\
Dye concentration, $\mathrm{mg} / \mathrm{L}$ & 30 & 30 \\
Enzyme concentration, $\mathrm{IU} / \mathrm{mL}$ & 0.15 & 0.15 \\
\hline
\end{tabular}

a similar trend was observed for AV 109 (insert in Figure 4(a)). Namely, an increase of dye removal can be noticed in the hydrogen peroxide concentration range of $0.2-0.6 \mathrm{mM}$ and at higher concentration, the decolorization range decreased. The inhibitory effect of hydrogen peroxide on HRP was also noticed by other researchers. For the removal of C.I. Acid Orange 7 from aqueous solution it was necessary to add hydrogen peroxide up to concentration of $0.8 \mathrm{mM}$ [32]. Similar behavior was noticed when the decolorization of an azo dye, C.I. Acid Blue 25, was studied showing that the optimal concentration of hydrogen peroxide was $0.8 \mathrm{mM}$. Hydrogen peroxide concentration higher than $0.8 \mathrm{mM}$ resulted in lower percent of dye removal in both cases. In order to avoid the inhibitory effect of hydrogen peroxide, different approaches have been used including the addition of glucose oxidase. Glucose oxidase produces hydrogen peroxide only in dose necessary for the reaction, so inhibitory effect of higher hydrogen peroxide concentration can be avoided [33].

Influence of the substrate concentration (dye) was examined by varying the concentration of dye in the range 10$50 \mathrm{mg} / \mathrm{L}$, and the results are shown in Figure 4(b). It seemed clear that there was also an optimum dye concentration for removal of both anthraquinonic dyes catalyzed by HRP. The optimal reaction values are presented in Table 3. Although there is no apparent substrate inhibition for AB 225, AV 109 seemed to act as a strong inhibitor at investigated conditions. However, at typical environmental dye concentrations, the HRP-catalyzed treatment process seemed also to be effective for this dye.

3.4. Initial $p H$ Influence. To examine influence of $\mathrm{pH}$ on decolorization reaction, $0.1 \mathrm{M}$ citrate buffer $(\mathrm{pH} 3-6)$ and $0.1 \mathrm{M}$ phosphate buffer ( $\mathrm{pH}$ 6-9) were used for both dyes (Figure 5).

Figure 5 clearly shows a rather high impact of $\mathrm{pH}$ on the enzyme activity. The bell-shaped curves with a defined $\mathrm{pH}$ optimum in the range from 4 to 5 were apparent for both dyes. In this $\mathrm{pH}$ range, an extremely high dye decolorization of 89.7 and $92.98 \%$ has been noticed for AV 109 and AB 225, respectively. This is an advantage from industrial application point of view since some dye effluents are slightly acidic [19]. On the other hand, in the $\mathrm{pH}$ range lower than 3.6 or higher than 6, a significant decrease in dye decolorization was observed, which can be attributed to the $\mathrm{pH}$-dependence of HRP activity [34]. Many substrates may have ionizable groups and only one of the ionized forms of the substrate may be acted upon by the enzyme, so one of the reasons 


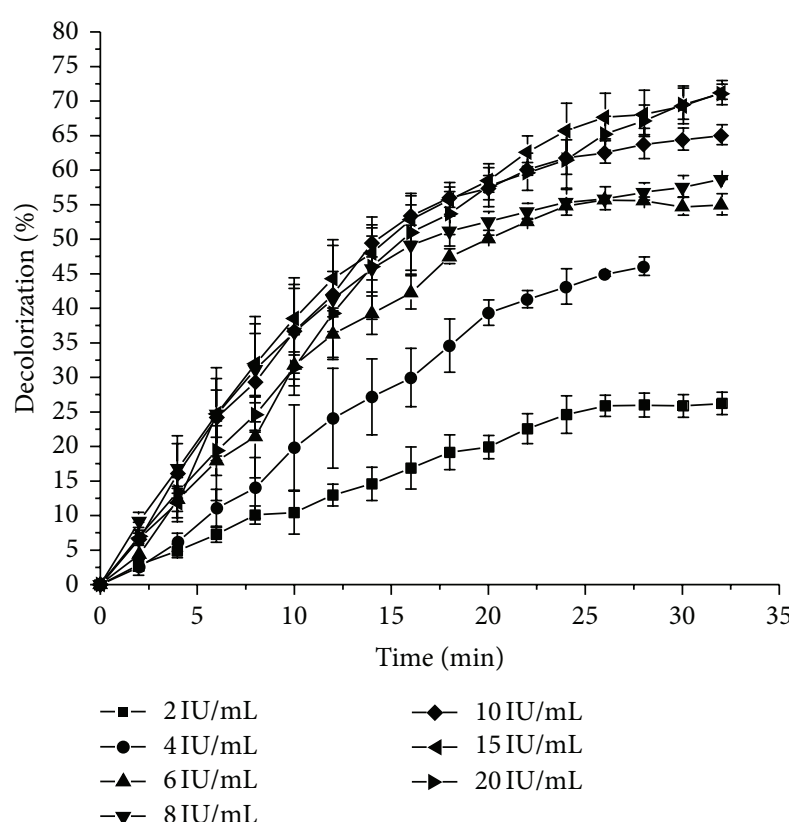

(a)

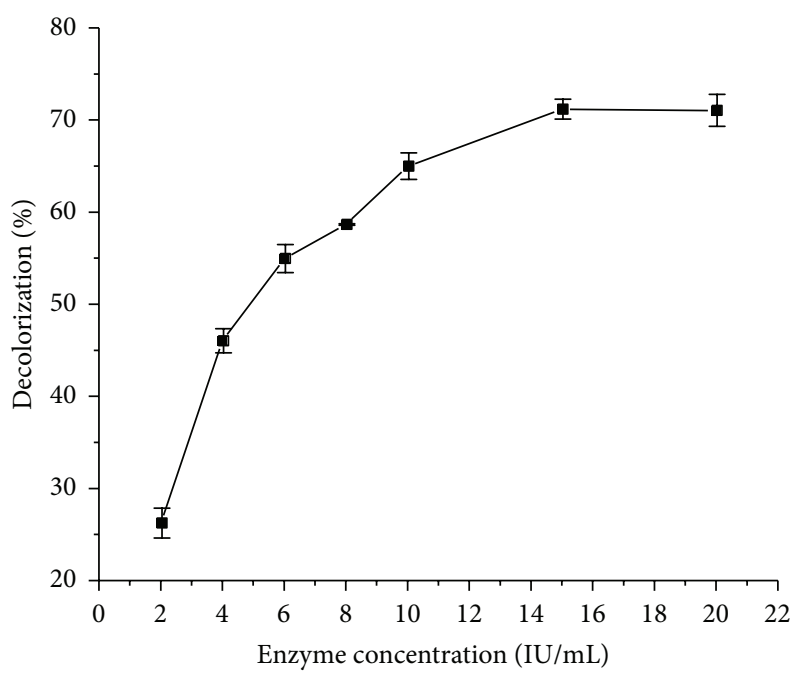

(c)

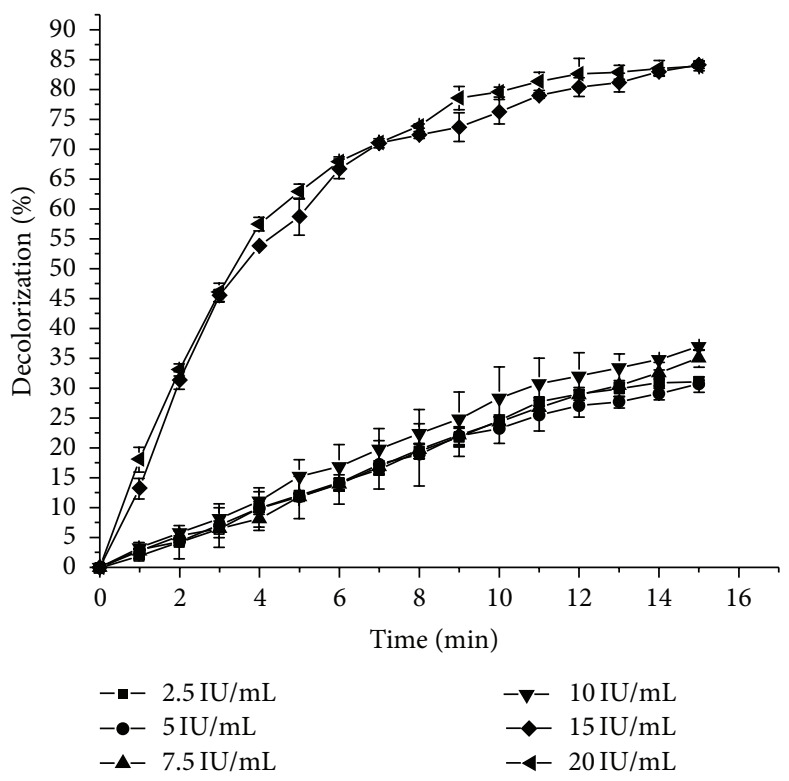

(b)

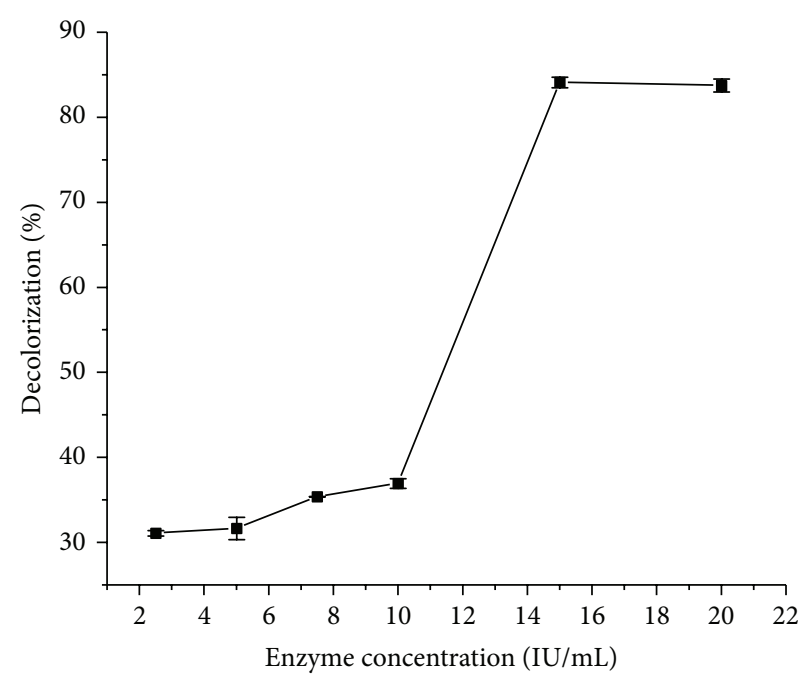

(d)

Figure 3: (a) Time course of decolorization of AB 225 and (b) AV 109 dyes at different initial enzyme concentration. (c) The influence of the initial enzyme concentration on the decolorization percentage for AB 225 and (d) AV 109. Reaction conditions for AB 225: treatment time 32 minutes, dye concentration $30 \mathrm{mg} / \mathrm{L}$, hydrogen peroxide concentration $1 \mathrm{mM}, \mathrm{pH} 5.25$, temperature $24^{\circ} \mathrm{C}$, and for $\mathrm{AV} 109$ : treatment time 15 minutes, dye concentration $30 \mathrm{mg} / \mathrm{L}$, hydrogen peroxide concentration $2 \mathrm{mM}$, temperature $24^{\circ} \mathrm{C}, \mathrm{pH} 5.5$. Each value represents the average of three experiments.

why at a $\mathrm{pH}$ below 3.6 and above 6 the small amount of dye is decolorized is that substrate is in that form so the enzyme cannot demonstrate its catalytic activity. Another reason can be that on either the basic or the acidic side of this $\mathrm{pH}$ optimum, the substantial structure changes in the enzyme may occur, causing a decline in the specific activity of the enzyme. It is well-known that the release of the heme group from the active site of the enzyme is $\mathrm{pH}$ dependent, occurring more rapidly below $\mathrm{pH} 4$ and leading to a loss of HRP activity [35]. The results are in contrast to the observations made for HRP-catalyzed degradation of Remazol Blue where an acid $\mathrm{pH}$ of 2.0 was found to be optimal, revealing that this azo dye acted as a strong competitive inhibitor of HRP at pH values above 6.0 [36]. Similarly, the decolorization efficiency of methyl orange decreased with the increase of $\mathrm{pH}$ value of the reaction mixture above 3.0, due to substrate inhibition at higher $\mathrm{pH}$ values [36]. Further experiments in this work were conducted in aqueous solutions with $\mathrm{pH} 4$ and 5 for $\mathrm{AV} 109$ and $\mathrm{AB}$ 225, respectively. 


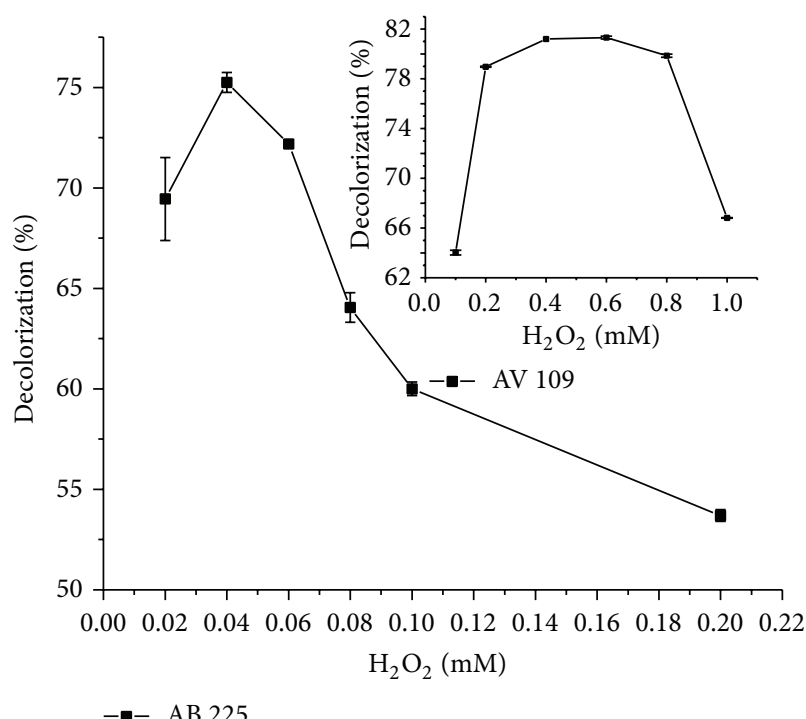

(a)

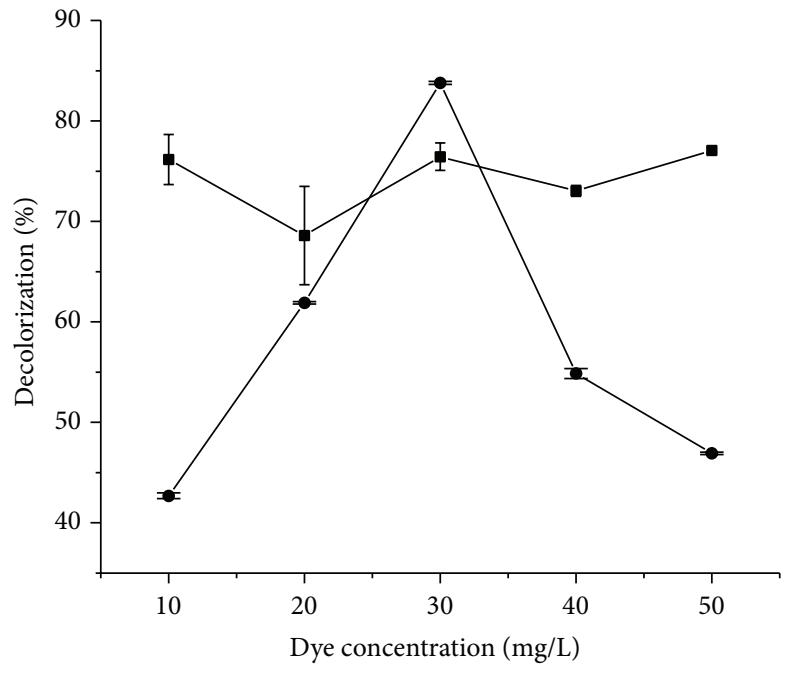

- - AB 225

AV 109

(b)

FIGURE 4: The decolorization percentage as a function of $\mathrm{H}_{2} \mathrm{O}_{2}$ concentration (a) and dye concentration (b). Reaction conditions for $\mathrm{AB} 225$ : reaction time 32 minutes, enzyme concentration $0.15 \mathrm{IU} / \mathrm{mL}, \mathrm{pH} 5.25$, and temperature $24^{\circ} \mathrm{C}$; for $\mathrm{AV}$ 109: reaction time 15 minutes, enzyme concentration $0.15 \mathrm{IU} / \mathrm{mL}, \mathrm{pH} 5.5$, and temperature $24^{\circ} \mathrm{C}$.

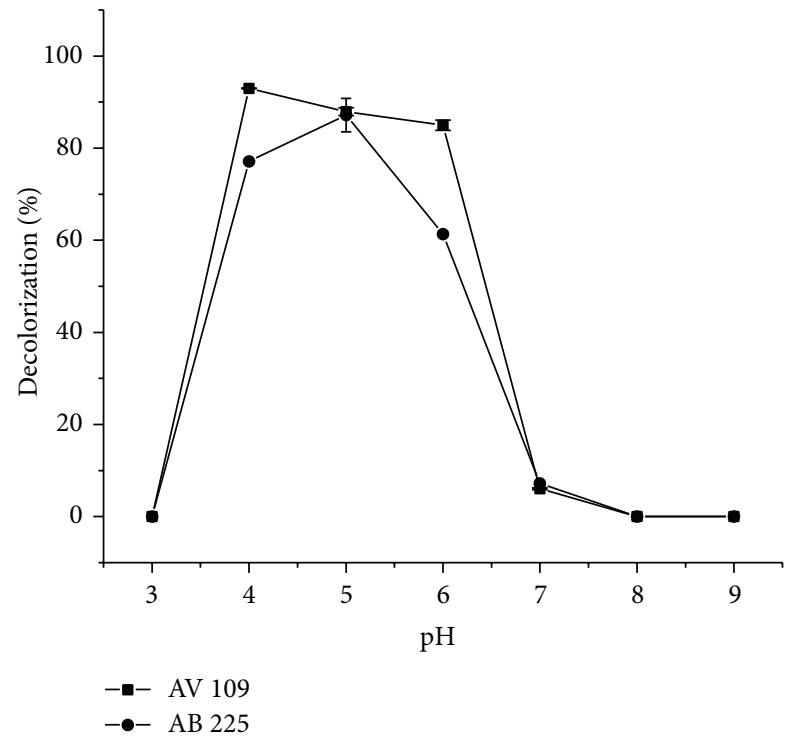

FIgURE 5: The influence of the initial pH on AB 225 and AV 109 decolorization at $24^{\circ} \mathrm{C}$ with $0.15 \mathrm{IU} / \mathrm{mL}$ HRP. Reaction conditions for $\mathrm{AB}$ 225: 32 minutes, dye concentration $30 \mathrm{mg} / \mathrm{L}$, and hydrogen peroxide concentration $0.04 \mathrm{mM}$; for AV 109: 15 minutes, dye concentration $30 \mathrm{mg} / \mathrm{L}$, and hydrogen peroxide concentration $0.4 \mathrm{mM}$. Relative standard deviations (RSD) of triplicate measurements were always less than $5 \%$.

3.5. Initial Temperature Influence. The influence of temperature on dyes removal was examined at the optimal $\mathrm{pH}$ for particular dye in the range $24-55^{\circ} \mathrm{C}$ (Figure 6). It appeared that the temperature profiles were similar for HRP

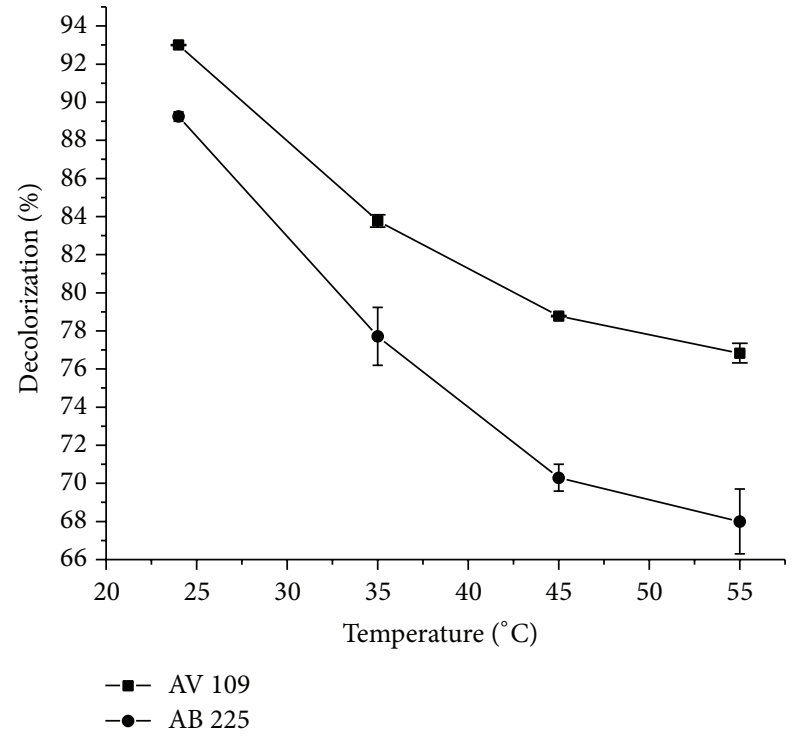

Figure 6: The influence of temperature on AB 225 and AV 109 decolorization. Other reaction conditions were optimal for both dyes.

degradation of both dyes. A typical bell-shaped curve with a defined temperature optimum was not obtained within the range tested. Namely, a rapid decrease in the activity was found with increasing temperature. The optimal temperature for the dye decolorization was accepted to be $24^{\circ} \mathrm{C}$. At the end, when the reactions were carried out under optimal conditions (Table 3), $94.7 \%$ of the AV 109 and $89.36 \%$ of the AB 225 dye were decolorized. The reported values of the optimal 
temperature for HRP varied, depending on the individual substrate.

3.6. The Initial Kinetic Study. HRP-catalyzed oxidation of organic substrates, using $\mathrm{H}_{2} \mathrm{O}_{2}$ (or other peroxides) as electron acceptor could be often described with a bisubstrate ping-pong kinetic model. The model is characterized by the product of the enzyme's reaction with the first substrate (in the case of peroxidases this is the reagent $\mathrm{H}_{2} \mathrm{O}_{2}$ ) being released before the reaction of the enzyme with the second substrate (anthraquinonic dye, DH). Specifically, $\mathrm{H}_{2} \mathrm{O}_{2}$ binds to the enzyme (E) in the first step of the ping-pong mechanism resulting in the formation of the oxidized form of the enzyme (EI, compound I) and a molecule of water. The produced compound $\mathrm{I}$ is then reduced by a hydrogen donor (dye, $\mathrm{DH}$, the second substrate in a ping-pong bi-bi mechanism) via a one-electron transfer process to form a second enzyme intermediate called compound II (EII) and a donor radical. Next step in the catalytic cycle of HRP is reduction of compound II again via a one-electron transfer process, returning the enzyme to its initial form, ready for the next catalytic cycle, and producing another donor radical [37-39].

The mechanism can be summarized by the following set of equations [25]:

$$
\begin{gathered}
\mathrm{E}+\mathrm{H}_{2} \mathrm{O}_{2} \stackrel{k_{1}}{\rightarrow} \mathrm{EI}+\mathrm{H}_{2} \mathrm{O} \\
\mathrm{EI}+\mathrm{DH} \stackrel{k_{2}}{\rightarrow} \mathrm{EII}+\mathrm{D}^{\bullet} \\
\mathrm{EII}+\mathrm{DH} \stackrel{k_{3}}{\rightarrow} \mathrm{D}^{\bullet}+\mathrm{E}+\mathrm{H}_{2} \mathrm{O}
\end{gathered}
$$

where $k_{1}, k_{2}$ and $k_{3}$ are reaction rate constants.

The net HRP-catalyzed reaction is summarized as follows:

$$
\mathrm{H}_{2} \mathrm{O}_{2}+2 \mathrm{DH} \stackrel{\mathrm{HRP}}{\longrightarrow} 2 \mathrm{D}^{\bullet}+\mathrm{H}_{2} \mathrm{O}
$$

This is the basic ping-pong model and it is well described by means of (6) (kinetic models for ping-pong bi-bi mechanisam with supstrate inhibition).

Ping-Pong mechanisam without inhibition:

$$
v_{0}=\frac{V_{\max }\left[\mathrm{H}_{2} \mathrm{O}_{2}\right]_{0}[\mathrm{D}]_{0}}{K_{m b}\left[\mathrm{H}_{2} \mathrm{O}_{2}\right]_{0}+K_{m a}[\mathrm{D}]_{0}+\left[\mathrm{H}_{2} \mathrm{O}_{2}\right]_{0}[\mathrm{D}]_{0}} .
$$

Ping-Pong mechanism with $\mathrm{H}_{2} \mathrm{O}_{2}$ inhibition:

$$
\begin{aligned}
v_{0}=( & \left.V_{\max }\left[\mathrm{H}_{2} \mathrm{O}_{2}\right]_{0}[\mathrm{D}]_{0}\right) \\
\times & \left(K_{m b}\left[\mathrm{H}_{2} \mathrm{O}_{2}\right]_{0}\left(1+\frac{\left[\mathrm{H}_{2} \mathrm{O}_{2}\right]_{0}}{K_{i a}}\right)\right. \\
& \left.+K_{m b}[\mathrm{D}]_{0}+\left[\mathrm{H}_{2} \mathrm{O}_{2}\right]_{0}[\mathrm{D}]_{0}\right)^{-1} .
\end{aligned}
$$

Ping-Pong mechanism with dye [D] inhibition

$$
\begin{aligned}
& v_{0} \\
& =\frac{V_{\max }\left[\mathrm{H}_{2} \mathrm{O}_{2}\right]_{0}[\mathrm{D}]_{0}}{K_{m b}\left[\mathrm{H}_{2} \mathrm{O}_{2}\right]_{0}+K_{m a}[\mathrm{D}]_{0}\left(1+[\mathrm{D}]_{0} / K_{i b}\right)+\left[\mathrm{H}_{2} \mathrm{O}_{2}\right]_{0}[\mathrm{D}]_{0}},
\end{aligned}
$$

$v_{0}$-initial rate of the reaction, $V_{\max }$-maximum rate, $\left[\mathrm{H}_{2} \mathrm{O}_{2}\right]_{0},[\mathrm{D}]_{0}$-initial concentrations of hydrogen peroxide and dye, respectively, $K_{m b}, K_{m a}-$ Michaelis constants for dye and hydrogen peroxide, respectively, $K_{i a}$, and $K_{i b}$-inhibition constants for hydrogen peroxide and dye, respectively.

In order to test the validity of the bisubstrate kinetic pingpong mechanism for the investigated HRP enzyme catalyzed oxidation reaction, the initial kinetic study was performed at previously determined optimum reaction parameters for both dyes. The experimental data obtained in both systems were fitted to a general two-substrate ping-pong kinetic model (three parameters, equation (6)) and a ping-pong kinetic model that includes peroxide inhibition (four parameters, equation (7)) or dye inhibition (four parameters, equation (8)).

Figures 7 and 8 show the experimentally obtained profiles for AV 109 and AB 225, respectively, and the fitted model values of the initial rate versus varying concentrations of one of the substrates, while the other one was kept constant.

The results indicated the presence of inhibition by both substrates. Namely, the experimentally obtained profiles of $V_{\max }$ against the concentration of both substrates had no a hyperbolic dependence characteristic for the ping-pong kinetic model. By contrast, the initial kinetic data for both dyes showed inhibition with increasing $\mathrm{H}_{2} \mathrm{O}_{2}$ and dye concentration (Figures 7 and 8).

Thus, the ping-pong kinetic model that includes inhibition, by forming a dead-end complex, has been proposed. According to this mechanism, since the three forms of the enzyme - E, compound I and compound II have a similar structure, it is reasonable to expect that dye $\mathrm{DH}$ has some affinity for E as well as for compounds I and II and or $\mathrm{H}_{2} \mathrm{O}_{2}$ also can show some affinity for compounds I or II, as shown on Scheme 1.

The best fit for experimental data obtained for both dyes was achieved when the ping-pong bi-bi mechanism with $\mathrm{H}_{2} \mathrm{O}_{2}$ inhibition was used, revealing the permanent enzyme inactivation in the presence of excess $\mathrm{H}_{2} \mathrm{O}_{2}$. The model concurred very well with the experimental data $\left(R^{2}=0.9902\right.$ and 0.9908 for AV 109 and AB 225 resp.). However, the basic ping-pong model seemed to underpredict the rate of dyes removal as rather high deviations of the experimental kinetic data from the theoretical fitted value were obtained for both dyes.

The slightly lower $K_{m}$ value for AB 225 suggested that HRP had higher apparent affinity toward this dye. However, from the inhibition constants values $\left(K_{i}\right)$ shown in Table 4, it can be concluded that the AV 109 dye exhibited a rather high inhibitory effect on HRP enzyme. By analyzing the values of the inhibition constant for dye $(0.008 \mathrm{mM})$ and inhibition constant for hydrogen peroxide $(0.4436 \mathrm{mM})$, it 


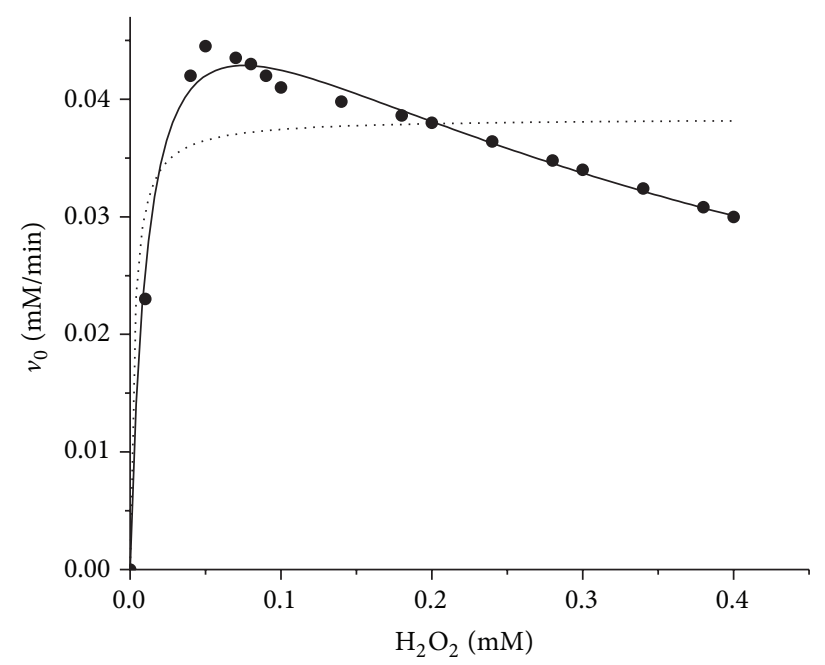

(a)

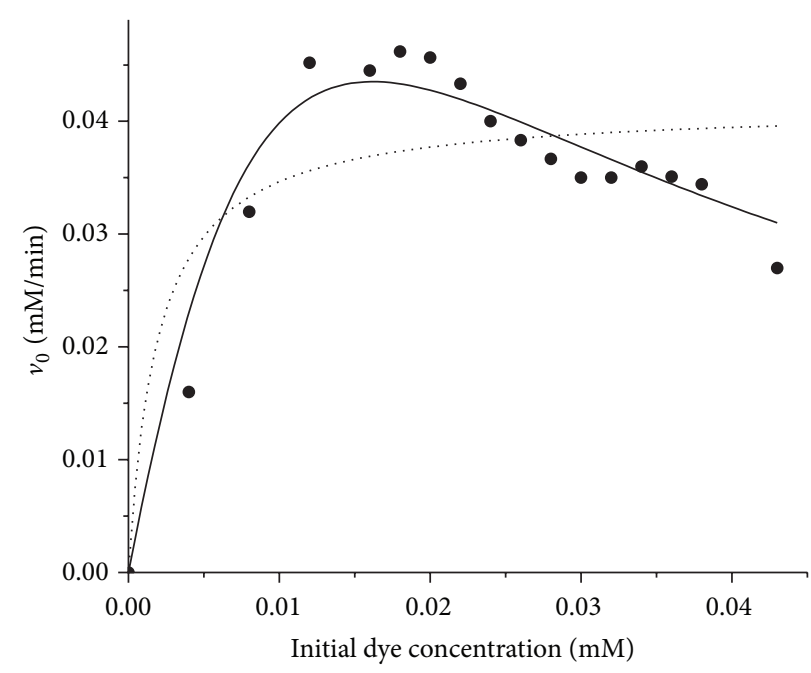

(b)

Figure 7: (a) Initial rate versus hydrogen peroxide concentration at fixed AV 109 concentration of $0.018 \mathrm{mM}$ and (b) initial rate versus AV 109 concentration at fixed hydrogen peroxide concentration of $0.06 \mathrm{mM}$. Symbols represent experimental data, lines indicate kinetic models based on fitted kinetic parameters including substrate inhibition (solid lines) and without substrate inhibition (dotted lines).

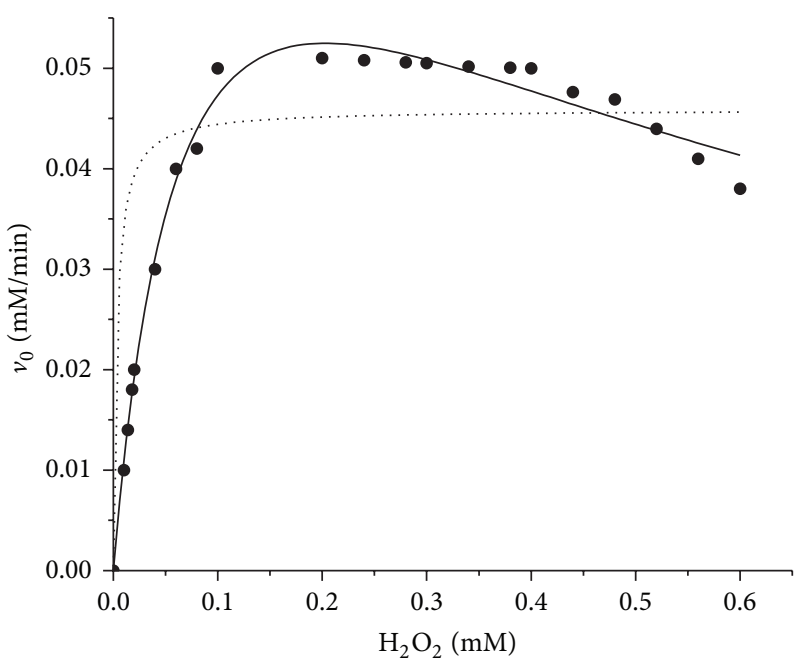

(a)

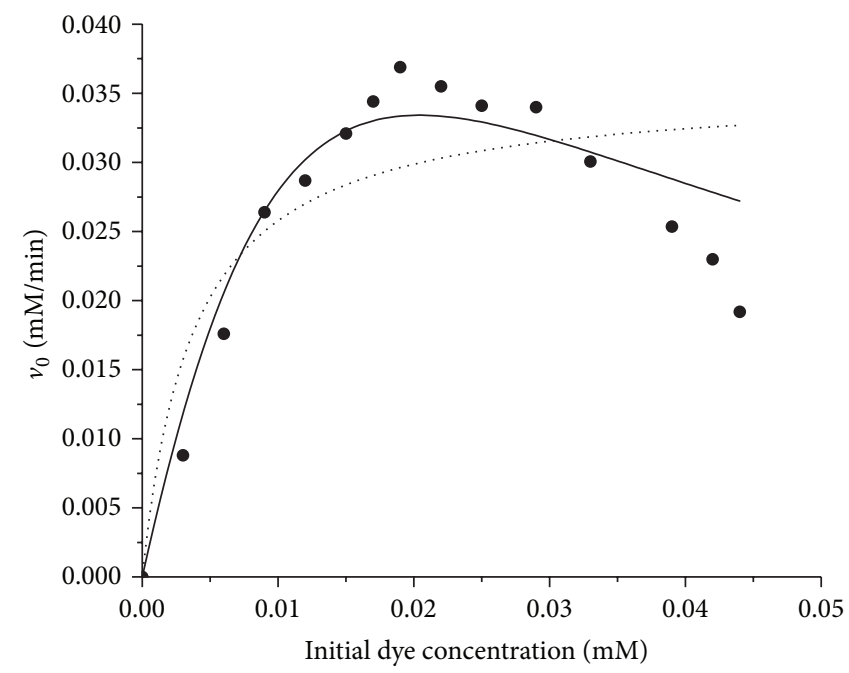

(b)

FIGURE 8: (a) Initial rate versus hydrogen peroxide concentration at fixed $\mathrm{AB} 225$ concentration of $0.029 \mathrm{mM}$ and (b) initial rate versus $\mathrm{AB}$ 225 concentration at fixed hydrogen peroxide concentration of $0.1 \mathrm{mM}$. Symbols represent experimental data, lines indicate kinetic models based on fitted kinetic parameters including substrate inhibition (solid lines) and without substrate inhibition (dotted lines).

can be concluded that in the case of AV 109, dye has stronger inhibitory effect on HRP enzyme. On the other hand, AB 225 showed similar effect. Namely, inhibition constant is $0.01259 \mathrm{mM}$ for dye, and $0.4767 \mathrm{mM}$ for hydrogen peroxide. However, by comparing the values of the inhibition constants of each of the examined dyes, it can be concluded that AV 109 is significantly higher potent inhibitor than $\mathrm{AB} 225$. These data were consistent with the previous optimization study, where a higher AV 109 concentration caused a sharp decline in the day decolorization. Ping-pong reaction kinetics has also been observed for several other peroxidase-catalyzed oxidations mediated by compound I; however, the inhibition by both substrates was often neglected.

3.7. COD and TOC. COD and TOC can be used to indirectly determine the amount of organic matter in water and wastewater and thus can be applied for evaluation of the efficiency of water treatment. The initial value of $\mathrm{COD}$ for $\mathrm{AB}$ 225 sample was $633 \mathrm{mg} \mathrm{O}_{2} / \mathrm{L}$. After the decolorization experiments, $\mathrm{COD}$ was determined to be $493 \mathrm{mg} \mathrm{O}_{2} / \mathrm{L}$ (decrease by $22 \%$ ). Similar behavior was noticed in the case of AV 109 . Namely, the sample had an initial value of $668 \mathrm{mg} \mathrm{O}_{2} / \mathrm{L}$, and 


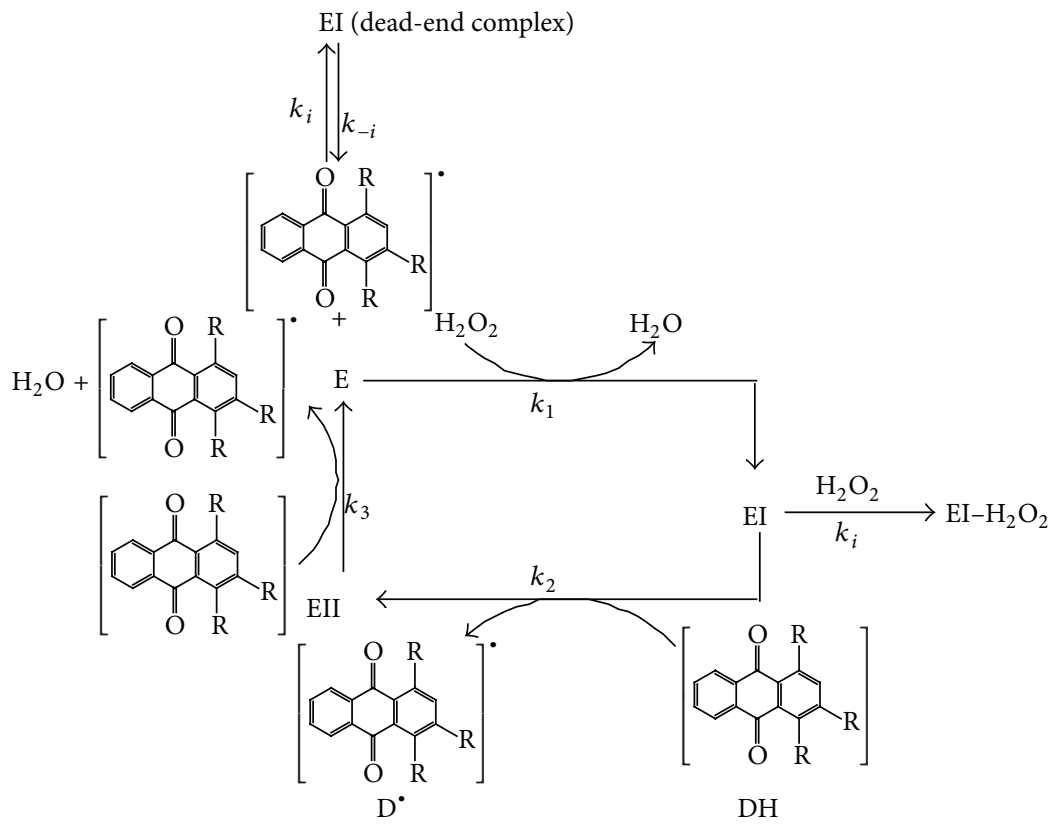

Scheme 1: Schematic representation of the ping-pong bi-bi mechanism with dye and $\mathrm{H}_{2} \mathrm{O}_{2}$ inhibition.

TABLE 4: Best fit of kinetic parameters obtained for the $\mathrm{H}_{2} \mathrm{O}_{2}$-mediated oxidation of AV 109 and AB 225 by HRP modeled by ping-pong bi-bi model considering inhibition with substrates and without inhibition.

\begin{tabular}{|c|c|c|c|c|}
\hline Kinetic parameters & $\begin{array}{c}\text { Dye } \\
\text { inhibition }\end{array}$ & $\begin{array}{l}\text { Without dye } \\
\text { inhibition }\end{array}$ & $\begin{array}{c}\text { Hydrogen peroxide } \\
\text { inhibition }\end{array}$ & $\begin{array}{l}\text { Without hydrogen } \\
\text { peroxide inhibition }\end{array}$ \\
\hline \multicolumn{5}{|l|}{ AV 109} \\
\hline$V_{\max }\left(\mathrm{mMmin}^{-1}\right)$ & 1.638 & 0.5178 & 1.097 & 1.185 \\
\hline$K_{m \mathrm{D}}(\mathrm{mM})$ & 0.2374 & 0.0245 & 0.3302 & 0.5373 \\
\hline$K_{i}(\mathrm{mM})$ & 0.0080 & l & 0.4436 & l \\
\hline$K_{m \mathrm{H}_{2} \mathrm{O}_{2}}(\mathrm{mM})$ & 0.4372 & 0.6908 & 0.2356 & 0.8081 \\
\hline$R^{2}$ & 0.9225 & 0.6456 & 0.9902 & 0.7520 \\
\hline \multicolumn{5}{|l|}{ AB 225} \\
\hline$V_{\max }\left(\mathrm{mMmin}^{-1}\right)$ & 0.9813 & 0.3266 & 0.5625 & 1.006 \\
\hline$K_{m \mathrm{D}}(\mathrm{mM})$ & 0.2213 & 0.03464 & 0.1522 & 0.6069 \\
\hline$K_{i}(\mathrm{mM})$ & 0.0126 & l & 0.4767 & l \\
\hline$K_{m \mathrm{H}_{2} \mathrm{O}_{2}}(\mathrm{mM})$ & 0.6685 & 0.8203 & 0.4536 & 0.0723 \\
\hline$R^{2}$ & 0.9602 & 0.7730 & 0.9908 & 0.9067 \\
\hline
\end{tabular}

$v_{0}$-initial rate of the reaction, $V_{\max }$-maximum rate, $\left[\mathrm{H}_{2} \mathrm{O}_{2}\right]_{0}$ and $[\mathrm{D}]_{0}$-initial concentrations of hydrogen peroxide and dye, respectively, $K_{m b}, K_{m a}-$ Michaelis constants for dye and hydrogen peroxide, respectively, $K_{i a}, K_{i b}$-inhibition constants for hydrogen peroxide and dye, respectively.

after the treatment there was a decrease in COD value to $488 \mathrm{O}_{2} / \mathrm{L}$ (decrease by $26 \%$ ). All these results showed that decolorization had influence on COD reduction. A strong correlation between the values of chemical oxygen demand and total organic carbon appeared. Namely, TOC analysis showed similar behavior and the value of total organic oxygen decreased by 14 and 38\% for AV 109 and AB 225, respectively.

\section{Conclusion}

It appears that HRP is a promising biocatalyst for the oxidative decolorization of anthraquinonic dyes. It was capable of achieving $94.7 \%$ removal of AV 109 and $89.36 \%$ removal of $\mathrm{AB} 225$ under optimal conditions after 15 and $32 \mathrm{~min}$ of treatment, respectively. The kinetic analysis was carried out at optimum operating conditions, revealing that the experimental kinetic data was adequately modelled by the ping-pong bi-bi kinetics with substrate inhibition. Overall, the high affinity of the enzyme to both dyes and a rather high percentage of decolorization, the $\mathrm{pH}$ optimum occurring in the range of some slightly acidic dye effluents have important implications for the potential of HRP in degradation of anthraquinonic dyes. However, the inactivation of the enzyme in the presence of the dyes can be the major limitation 
in potential commercial application of the technique for anthraquinonic dye removal. Thus, additional investigations and development could be carried out to improve the decolorization process, including immobilization of the enzyme and its application for real industrial substrate decolorization in the presence of competitive matters.

\section{Conflict of Interests}

The authors declare that there is no conflict of interests regarding the publication of this paper.

\section{Acknowledgment}

The authors acknowledge the financial support of the Ministry of Education, Science and Technological Development of the Republic of Serbia (Project nos. III-46010 and 172013).

\section{References}

[1] A. R. Tehrani-Bagha and K. Holmberg, "Solubilization of hydrophobic dyes in surfactant solutions," Materials, vol. 6, no. 2, pp. 580-608, 2013.

[2] N. M. Julkapli, S. Bagheri, and S. B. A. Hamid, "Recent advances in heterogeneous photocatalytic decolorization of synthetic dyes," The Scientific World Journal, vol. 2014, Article ID 692307, 25 pages, 2014.

[3] I. M. Banat, P. Nigam, D. Singh, and R. Marchant, "Microbial decolorization of textile-dye-containing effluents: a review," Bioresource Technology, vol. 58, no. 3, pp. 217-227, 1996.

[4] S. Wijetunga, X.-F. Li, and C. Jian, "Effect of organic load on decolourization of textile wastewater containing acid dyes in upflow anaerobic sludge blanket reactor," Journal of Hazardous Materials, vol. 177, no. 1-3, pp. 792-798, 2010.

[5] G. S. Nyanhongo, J. Gomes, G. M. Gübitz, R. Zvauya, J. Read, and W. Steiner, "Decolorization of textile dyes by laccases from a newly isolated strain of Trametes modesta," Water Research, vol. 36, no. 6, pp. 1449-1456, 2002.

[6] S. Song, J. Yao, Z. He, J. Qiu, and J. Chen, "Effect of operational parameters on the decolorization of C.I. Reactive blue 19 in aqueous solution by ozone-enhanced electrocoagulation," Journal of Hazardous Materials, vol. 151, no. 1, pp. 204-210, 2008.

[7] M. Celebi, M. Altikatoglu, Z. M. Akdeste, and H. Yildirim, "Determination of decolorization properties of reactive blue 19 dye using horseradish peroxidase enzyme," Turkish Journal of Biochemistry, vol. 38, no. 2, pp. 200-206, 2013.

[8] A. B. dos Santos, F. J. Cervantes, and J. B. van Lier, "Review paper on current technologies for decolourisation of textile wastewaters: perspectives for anaerobic biotechnology," Bioresource Technology, vol. 98, no. 12, pp. 2369-2385, 2007.

[9] J. Liu and G. Sun, "The biocidal properties of anthraquininoid dyes," Dyes and Pigments, vol. 81, no. 3, pp. 231-234, 2009.

[10] Č. Novotný, N. Dias, A. Kapanen et al., "Comparative use of bacterial, algal and protozoan tests to study toxicity of azo- and anthraquinone dyes," Chemosphere, vol. 63, no. 9, pp. 1436-1442, 2006.

[11] T. Robinson, G. McMullan, R. Marchant, and P. Nigam, "Remediation of dyes in textile effluent: a critical review on current treatment technologies with a proposed alternative," Bioresource Technology, vol. 77, no. 3, pp. 247-255, 2001.
[12] G. McMullan, C. Meehan, A. Conneely et al., "Microbial decolourisation and degradation of textile dyes," Applied Microbiology and Biotechnology, vol. 56, no. 1-2, pp. 81-87, 2001.

[13] S. Andleeb, N. Atiq, G. D. Robson, and S. Ahmed, "An investigation of anthraquinone dye biodegradation by immobilized Aspergillus flavus in fluidized bed bioreactor," Environmental Science and Pollution Research, vol. 19, no. 5, pp. 1728-1737, 2012.

[14] G. Arroyo-Figueroa, G. M. L. Ruiz-Aguilar, L. López-Martínez, G. González-Sánchez, G. Cuevas-Rodríguez, and R. RodríguezVázquez, "Treatment of a textile effluent from dyeing with cochineal extracts using Trametes versicolor fungus," The Scientific World Journal, vol. 11, pp. 1005-1016, 2011.

[15] G. Arabaci and A. Usluoglu, "The enzymatic decolorization of textile dyes by the immobilized polyphenol oxidase from quince leaves," The Scientific World Journal, vol. 2014, Article ID 685975 , 5 pages, 2014.

[16] Q. Husain, "Peroxidase mediated decolorization and remediation of wastewater containing industrial dyes: a review," Reviews in Environmental Science and Biotechnology, vol. 9, no. 2, pp. 117140, 2010.

[17] F. Ghasemi, F. Tabandeh, B. Bambai, and K. R. S. S. Rao, "Decolorization of different azo dyes by Phanerochaete chrysosporium RP78 under optimal condition," International Journal of Environmental Science and Technology, vol. 7, no. 3, pp. 457-464, 2010.

[18] P. Ollikka, T. Harjunpa, K. Palmu, P. Mantsala, and I. Suominen, "Oxidation of crocein Orange $\mathrm{G}$ by lignin peroxidase isoenzymes: kinetics and effect of $\mathrm{H}_{2} \mathrm{O}_{2}$," Applied Biochemistry and Biotechnology, vol. 75, no. 2-3, pp. 307-321, 1998.

[19] N. Bansal and S. S. Kanwar, "Peroxidase(s) in environment protection," The Scientific World Journal, vol. 2013, Article ID 714639, 9 pages, 2013.

[20] A. Zhang, L. Fang, J. Wang, and W. Liu, "Enzymatic decolorization of Orange II: optimization by response surface methodology and pathway," Environmental Progress and Sustainable Energy, vol. 32, no. 2, pp. 294-301, 2013.

[21] L. Liu, J. Zhang, Y. Tan et al., "Rapid decolorization of anthraquinone and triphenylmethane dye using chloroperoxidase: catalytic mechanism, analysis of products and degradation route," Chemical Engineering Journal, vol. 244, pp. 9-18, 2014.

[22] A. Bhunia, S. Durani, and P. P. Wangikar, "Horseradish peroxidase catalyzed degradation of industrially important dyes," Biotechnology and Bioengineering, vol. 72, no. 5, pp. 562-567, 2001.

[23] S. V. Mohan, K. K. Prasad, N. C. Rao, and P. N. Sarma, "Acid azo dye degradation by free and immobilized horseradish peroxidase (HRP) catalyzed process," Chemosphere, vol. 58, no. 8, pp. 1097-1105, 2005.

[24] S. M. A. G. Ulson de Souza, E. Forgiarini, and A. A. Ulson de Souza, "Toxicity of textile dyes and their degradation by the enzyme horseradish peroxidase (HRP)," Journal of Hazardous Materials, vol. 147, no. 3, pp. 1073-1078, 2007.

[25] G. Bayramoǧlu and M. Y. Arica, "Enzymatic removal of phenol and $p$-chlorophenol in enzyme reactor: horseradish peroxidase immobilized on magnetic beads," Journal of Hazardous Materials, vol. 156, no. 1-3, pp. 148-155, 2008.

[26] S. Onder, M. Celebi, M. Altikatoglu, A. Hatipoglu, and H. Kuzu, "Decolorization of naphthol blue black using the horseradish peroxidase," Applied Biochemistry and Biotechnology, vol. 163, no. 3, pp. 433-443, 2011.

[27] F. Gholami-Borujeni, M. A. Faramarzi, F. NejatzadehBarandozi, and A. H. Mahvi, "Oxidative degradation and 
detoxification of textile azo dye by horseradish peroxidase enzyme," Fresenius Environmental Bulletin, vol. 22, no. 3, pp. 739-744, 2013.

[28] S. V. Surwase, K. K. Desphande, S. S. Phurage, and J. P. Jadhav, "Biotransformation studies on textile dye Remazol Orange 3R," 3 Biotech, vol. 3, no. 4, pp. 267-275, 2013.

[29] P. Peralta-Zamora, C. M. Pereira, E. R. L. Tiburtius et al., "Decolorization of reactive dyes by immobilized laccase," Applied Catalysis B: Environmental, vol. 42, no. 2, pp. 131-144, 2003.

[30] T. Hadibarata, L. A. Adnan, A. R. M. Yusoff et al., "Microbial decolorization of an azo dye reactive black 5 using white-rot fungus Pleurotus eryngii Fo32," Water, Air, and Soil Pollution, vol. 224, no. 6, article 1595, 2013.

[31] C. S. Tsai, An Introduction to Computational Biochemistry, John Wiley \& Sons, New York, NY, USA, 2002.

[32] F. Gholami-Borujeni, A. H. Mahvi, S. Nasseri, M. A. Faramarzi, R. Nabizadeh, and M. Alimohammadi, "Enzymatic treatment and detoxification of Acid Orange 7 from textile wastewater," Applied Biochemistry and Biotechnology, vol. 165, no. 5-6, pp. 1274-1284, 2011.

[33] J. Lan, X. Huang, M. Hu et al., "High efficient degradation of dyes with lignin peroxidase coupled with glucose oxidase," Journal of Biotechnology, vol. 123, no. 4, pp. 483-490, 2006.

[34] Y. Wu, K. E. Taylor, N. Biswas, and J. K. Bewtra, "Comparison of additives in the removal of phenolic compounds by peroxidasecatalyzed polymerization," Water Research, vol. 31, no. 11, pp. 2699-2704, 1997.

[35] T. Thongsook and D. M. Barrett, "Purification and partial characterization of broccoli (Brassica oleracea Var. Italica) peroxidases," Journal of Agricultural and Food Chemistry, vol. 53, no. 8, pp. 3206-3214, 2005.

[36] A. Bhunia, S. Durani, and P. P. Wangikar, "Horseradish peroxidase catalyzed degradation of industrially important dyes," Biotechnology and Bioengineering, vol. 72, no. 5, pp. 562-567, 2001.

[37] A. N. P. Hiner, E. L. Raven, R. N. F. Thorneley, F. GarcíaCánovas, and J. N. Rodríguez-López, "Mechanisms of compound I formation in heme peroxidases," Journal of Inorganic Biochemistry, vol. 91, no. 1, pp. 27-34, 2002.

[38] F. Deyhimi and F. Nami, "Peroxidase-catalyzed electrochemical assay of hydrogen peroxide: a ping-pong mechanism," International Journal of Chemical Kinetics, vol. 44, no. 10, pp. 699-704, 2012.

[39] U. Bandyopadhyay, S. Adak, and R. K. Banerjee, "Role of active site residues in peroxidase catalysis: studies on horseradish peroxidase," Proceedings of the Indian National Science Academy, vol. B65, no. 5, pp. 315-330, 1999. 

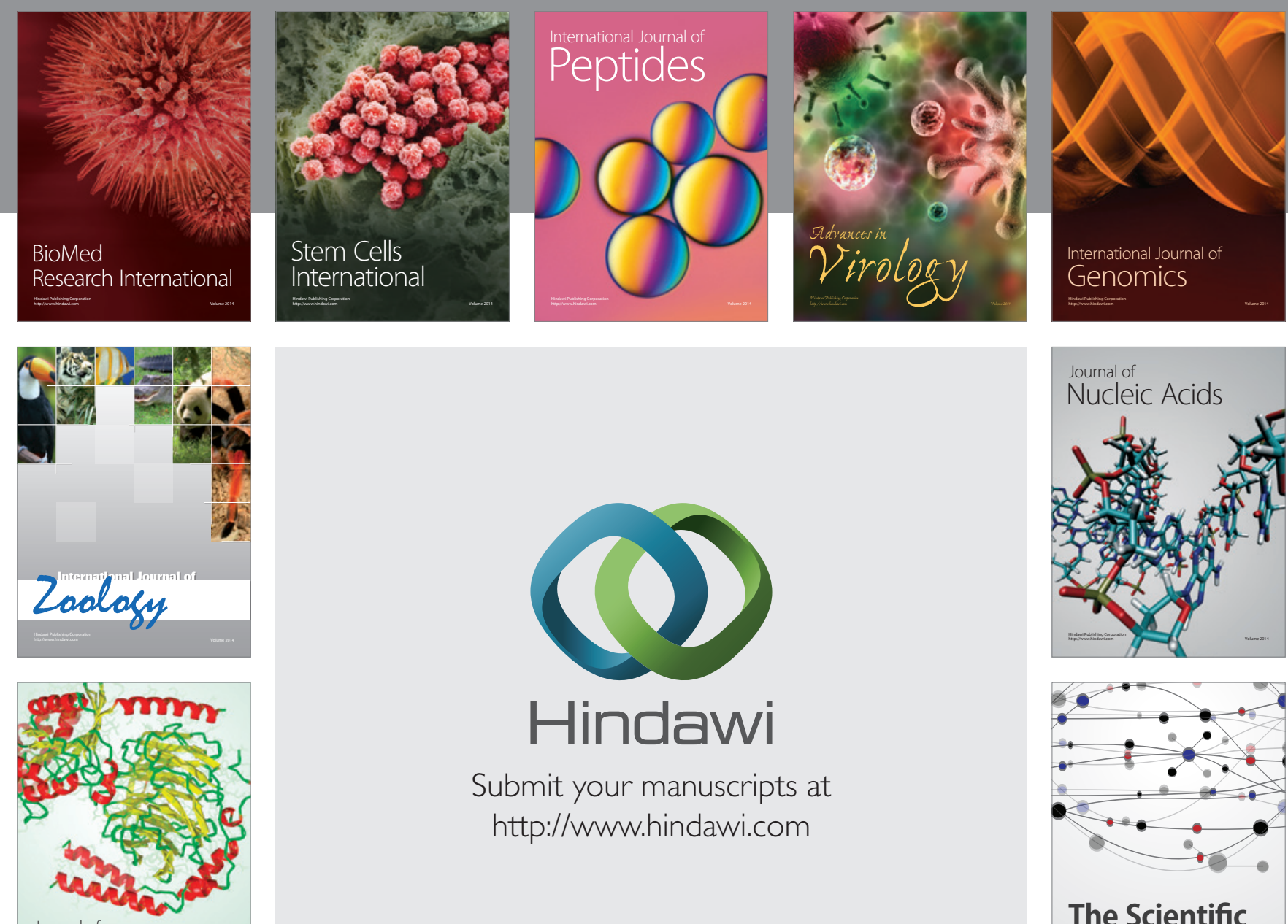

Submit your manuscripts at

http://www.hindawi.com

Journal of
Signal Transduction
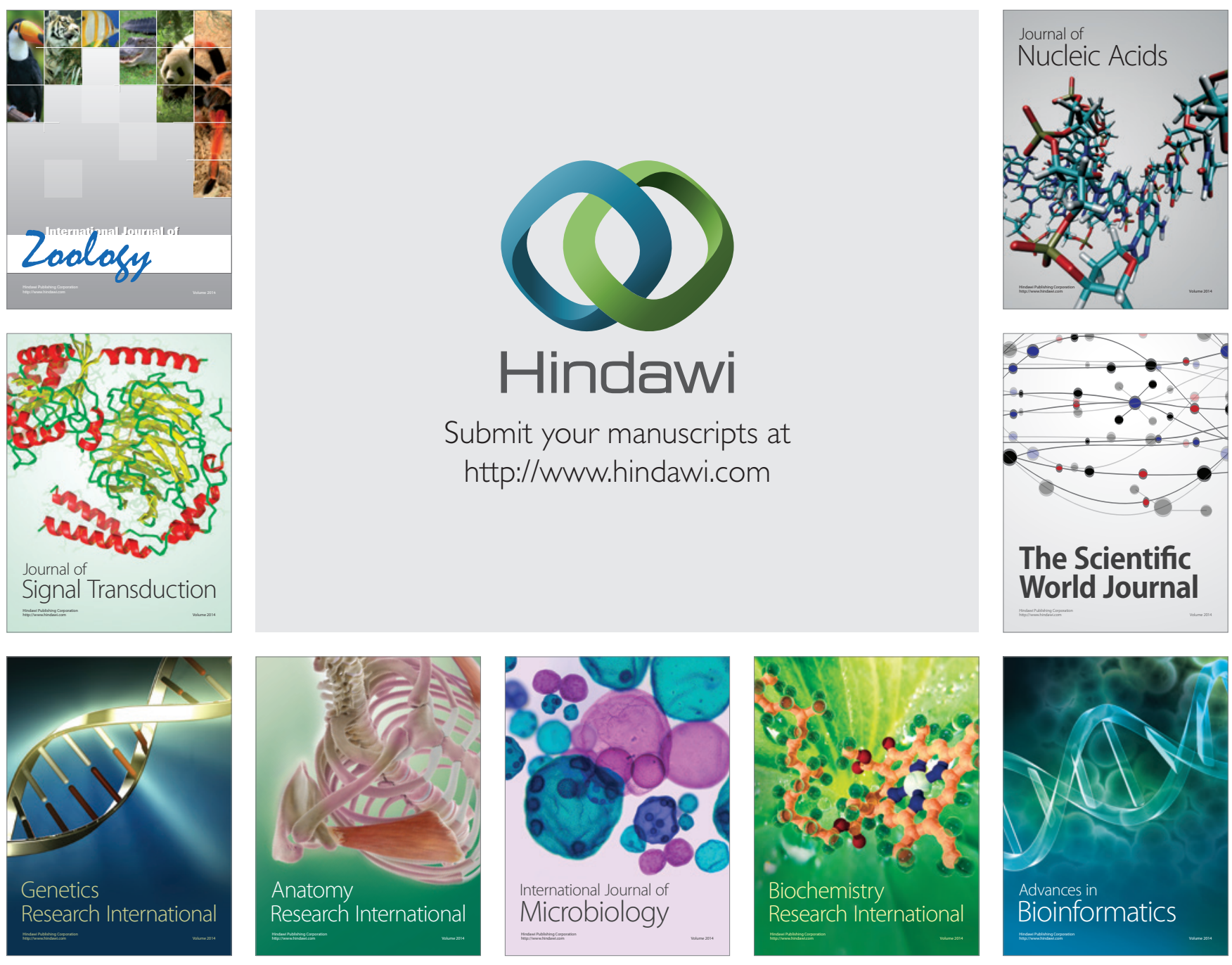

The Scientific World Journal
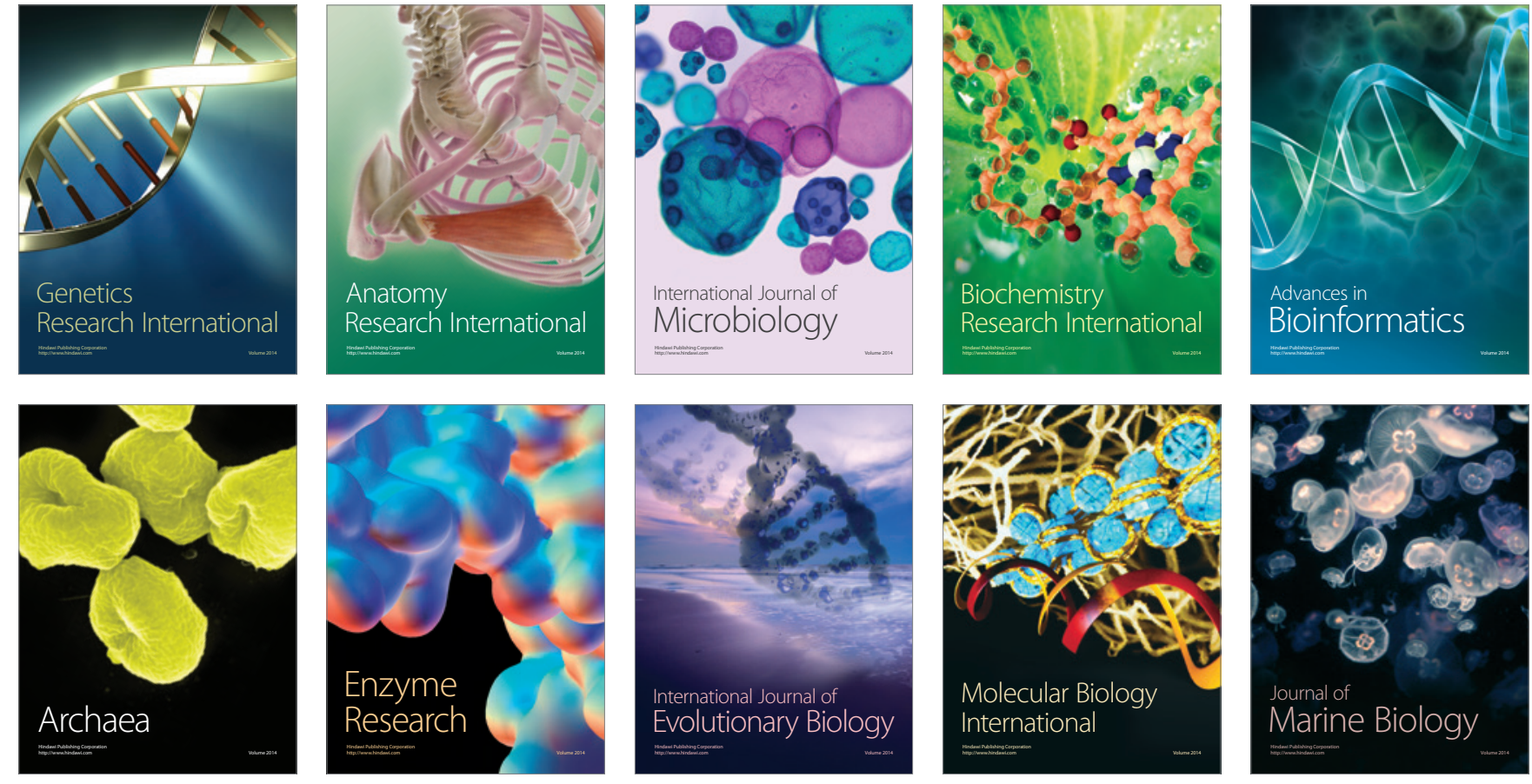